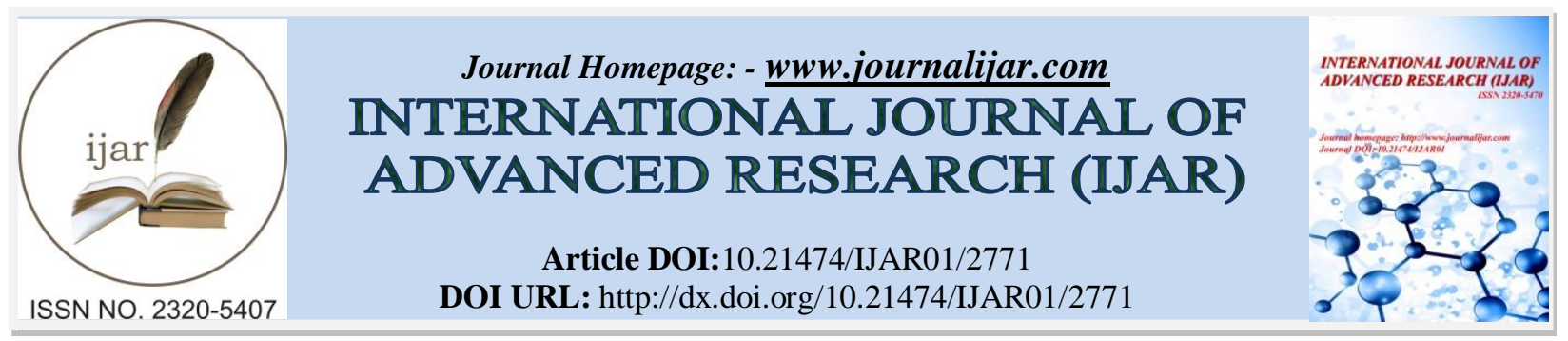

RESEARCH ARTICLE

\title{
A STUDY ON MSME PROFITABILITY IN CONNECTION WITH POOR MARKET LINKAGE
}

Ms. M. Farhana ${ }^{1}$ and Mr. P S. Anil ${ }^{2}$.

1. Pursuing MBA (Finance \& Operations), Gnanam School of Business, Thanjavur.

2. Associate Professor, Gnanam School of Business, Thanjavur.

\section{Manuscript Info}

\section{Manuscript History}

Received: 15 November 2016

Final Accepted: 17 December 2016

Published: January 2017

Key words:-

MSME,Linkage,Market

connection,profitability

\section{Abstract}

MSME is the most developed sector in India. It contributes the growth in GDP. This article is mainly concerned with micro,small and medium enterprises (MSMEs) and its market linkage based on their profitability.MSME plays a crucial role to India to generating employment and contributing to regional economic growth.It gives opportunity to rural people those who have minimum capital to invest in small business and male earnings on the daily or weekly basis.To start MSME, the people should utilize all the optimum resources available in their place. This paper presents the consequences the MSME faced by to get linkage with top companies.The level of profitability should lead linkage with other companies. This article gives brief idea about the MSME and importance of their market linkage.

Copy Right, IJAR, 2016,. All rights reserved.

\section{Introduction:-}

In India MSME plays a vital role in the economic development of the nation by contributing $11.5 \%$ of GDP consistently every year. It is a stimulus for the socio economic transformation of the societynot only by generating employment opportunities in both rural and urban areas of the country but also by promoting rapid industrialization in the country to the length and breadth of the country eliminating regional imbalances. The sector identification and the requirements of the area and utilization of the available recourses locally to reduce the cost of production is the most important factor of this sector. It helps a lot to prevent poverty and rural migration to towns in search of employment.

The Sector consisting of 36 million units, as of today, provides employment to over 80 million persons. The Sector through more than 6,000 products contributes about $8 \%$ to GDP besides $45 \%$ to the total manufacturing output and $40 \%$ to the exports from the country. The MSME sector has the potential tospread industrial growth across the country and can be a major partner in the process of inclusive growth.

\section{Objectives:-}

1. To understand the impact of poor profitability of poor market linkage

2. To overall study of the relevance of MSME in Indian economy

3. To general study about MSME and helps to contribute our GDP

4. To review the challenges to be faced by MSMEs in India 


\section{Understanding msme:-}

Understanding MSME:

'The MSME Act 2006' modifies the definition of MSME in India. Under the said Act, the sector is broadly classified into two parts, manufacturing and service. The unit is identified based on investment made as shown in the following table.

\begin{tabular}{|l|l|l|}
\hline & MANUFACTURING UNIT & SERVICE UNIT \\
\hline A micro enterprise & $\begin{array}{l}\text { Investment in plant and machinery does not } \\
\text { exceed Rs.25 lakhs }\end{array}$ & $\begin{array}{l}\text { Investment in equipment's does not } \\
\text { exceed Rs.10 lakhs }\end{array}$ \\
\hline A small enterprise & $\begin{array}{l}\text { Investment in plant and machinery is more } \\
\text { than Rs.25 lakhs but does not exceed Rs.5 } \\
\text { crores }\end{array}$ & $\begin{array}{l}\text { Investment in equipment is more than } \\
\text { Rs.10 lakhs but does not exceed Rs.2 } \\
\text { crores }\end{array}$ \\
\hline A medium enterprise & $\begin{array}{l}\text { Investment in plant and machinery is more } \\
\text { than Rs.5crores but does not exceed Rs.10 } \\
\text { crores }\end{array}$ & $\begin{array}{l}\text { Investment in equipment is more than } \\
\text { Rs.2 crores but does not exceed Rs.5 } \\
\text { crores }\end{array}$ \\
\hline
\end{tabular}

Micro Small Medium Enterprise Development (MSMED) act definition of MSME:-

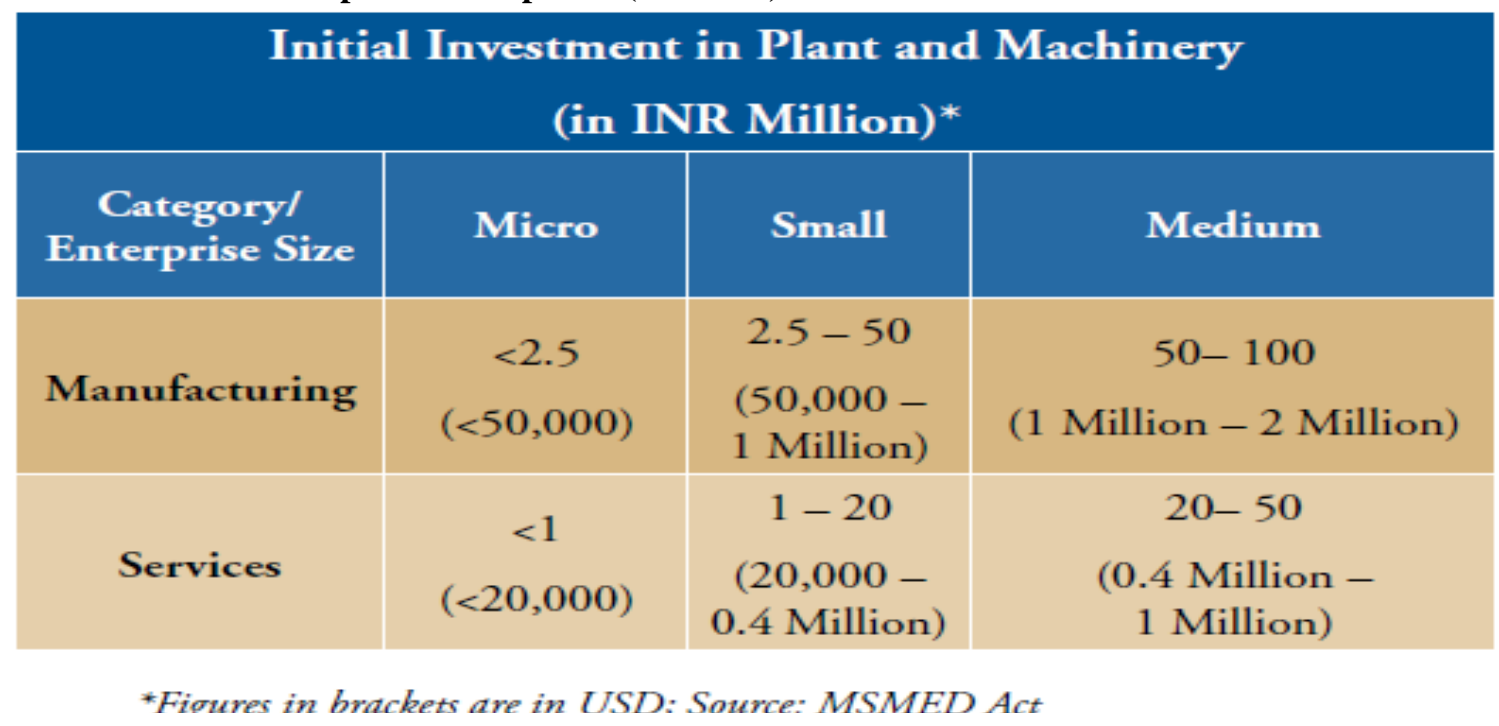

As per the private financial institutions in India, the internal definition of MSME can be explained with the help of the following table.

Internal Definitions used by Private Financial Institutions (Indicative):-

\begin{tabular}{|c|c|c|c|c|c|c|}
\hline \multicolumn{7}{|c|}{ INTERNAL DEFINITIONS USED BY BANKS FOR MSME } \\
\hline $\begin{array}{l}\text { ENTERPRI- } \\
\text { SE SIZF }\end{array}$ & \multicolumn{2}{|l|}{ MICRO } & \multicolumn{2}{|c|}{ SMALL } & \multicolumn{2}{|l|}{ MEDIUM } \\
\hline $\begin{array}{l}\text { Institution } \\
\text { Type }\end{array}$ & $\begin{array}{l}\text { Turnover(INR } \\
\text { Million) }\end{array}$ & $\begin{array}{l}\text { Credit } \\
\text { Size } \\
\text { (INR } \\
\text { Million) } \\
\end{array}$ & $\begin{array}{l}\text { Turnover(INR } \\
\text { Million) }\end{array}$ & $\begin{array}{l}\text { Credit Size } \\
\text { (INR } \\
\text { Million) }\end{array}$ & $\begin{array}{l}\text { Turnover } \\
\text { (INR Million) }\end{array}$ & $\begin{array}{l}\text { Credit } \\
\text { Size(INR } \\
\text { Million) }\end{array}$ \\
\hline $\begin{array}{l}\text { Private } \\
\text { Commercial } \\
\text { Banks }\end{array}$ & $\begin{array}{l}1.5-50(30000- \\
1 \text { million) }\end{array}$ & $\begin{array}{l}0.2-1 \\
(4000- \\
20000)\end{array}$ & $\begin{array}{l}50-200 \\
\text { million-4 } \\
\text { million) }\end{array}$ & $\begin{array}{lr}5-150 & (0.1 \\
\text { million } & -\quad 3 \\
\text { million }) & \\
\end{array}$ & $\begin{array}{l}200- \\
2000 \text { (4million- } \\
40 \text { million) }\end{array}$ & $\begin{array}{l}50-200(1 \text { million } \\
-4 \text { million })\end{array}$ \\
\hline $\begin{array}{l}\text { Non- } \\
\text { banking } \\
\text { financial } \\
\text { companies }\end{array}$ & $\begin{array}{l}0.05-1 \\
20000)\end{array}$ & $\begin{array}{l}1-5 \\
(20000- \\
0.1 \\
\text { million) }\end{array}$ & $\begin{array}{lr}5-25 & (0.1 \\
\text { million- } & 0.5 \\
\text { million) } & \end{array}$ & $\begin{array}{l}0.3-5 \\
(6000-0.1 \\
\text { million) }\end{array}$ & $\begin{array}{l}10-1000 \\
\text { ( } 0.2 \text { million- } \\
20 \text { million) }\end{array}$ & $\begin{array}{l}2.5-50 \\
(50000- \\
\text { million) }\end{array}$ \\
\hline
\end{tabular}

Source: Primary Research

However, all should use the official definition given by the MSMED Act for reporting purposes. 


\section{Online Indian MSME's finance providers:-}

In India, only less number of players are there who provide money to MSME through online. The online startup have shown interest towards starting new business. The finance service providers collectively have disbursed loans worth INR million in 2015. Some companies launched their operations in 2015. The online market for MSME finance in India has seen presence of players such as Faircent, Indifi technologies, Leading kart, ME Corner, Capital Float, Mandii.com and others.

\section{MSME's in India: challenges and opportunities:-}

The MSME is a highly unorganized sector even though it highly contribute in multiple ways towards the economy. Being a highly unorganized sector with fragmented nature of reach, the sector has always been a laggard in enjoying the full flow of Government policies and financing company's empathy and understanding. In order to understand the obstacles ; probable steps to be taken to exploit the opportunities offered by MSMEs, lets discuss the details of the working dynamics of MSMEs as under:

\section{Shortage of finance and credit instruments:-}

Finance is the major constraints of all the business especially it is very high in MSME. Most Indian MSMEs start out with minimal capital, which eventually stalls their growth after a certain point. The lack of easy credit tends to stagnate the growth of MSMEs, which in turn affecting generic growth in terms of GDP, import, export and employment. Unavailability of credit at the right time can also affect business growth at many seals leading to many small businesses shutting shop due to inadequate margins. Some major problems that approximately $80 \%$ MSME Entrepreneurs face on a day-to-day basis while trying to obtain credit assistance for their business operations are:

1. Need more collateral security to get loan

2. Import Export cost

3. To obtain of Private Equity Funding is difficult

4. Banks offer high rates for term loans

5. Private equity (PE) dilutes control in the company

6. Un-standardized project appraisal system for term loans

\section{Complicated Regulatory Policies for Starting a Business:-}

India is ranked at 130th position out of 189 countries who participated in the World Bank's Ease of Doing Business Rankingprimarily due to unfavorable business climate for its enterprises, especially the MSMEs. India is full of regulatory policies like taxation, dealing with construction permits, registering property, enforcing contract, resolving insolvency, etc. Indian MSMEs are weighed down by inflexible and complicated regulatory policies like Owing to this prohibitive business climate, this leads toomany innovative entrepreneurs and are not able to enter the markets or sustain a business. The following points show a breakdown of how inflexible regulatory policies affect the functioning of MSMEs :

1. Absence of a common regulatory body

2. Procedures of setting up business is complicated

3. Less special schemes for start-ups

4. Book keeping regulations is difficult

\section{Unavailability of modern, affordable technology:-}

In a present competitive business environment, the need to align people processes and technology is stronger than ever. Latest technology can help enterprises reduce cost and time taken to innovate and offer sophisticated products and services. To adopting new technology, helps toMSMEs differentiate from peers, optimize cost structures and most importantly compete on a global level. However, MSMEs in India face struggles because of accessing and using the latest technological advancements. While knowledge, access and funds continue to implementation of technology, absence of an ecosystem that enables technology transfer and interaction with experts is a critical reason of limited adoption. The absence of a common platform for interaction with technology providers continues to be the most critical challenge faced by MSMEs in this area. The below mentioned are the key reasons why MSMEs fail to adopt latest technology to innovate and transform their businesses.

1. MSME have less number of linkage so there is less interaction between tech providers and seekers

2. Ecosystem for technology transfer is absence

3. To Access modern technology is expensive 
4. MSME have only minimum knowledge about upcoming technologies

5. Unavailability of e-Governance systems

6. Lack of effective information systems

7. Limited funds to support Innovation and R\&D

\section{Lack of basic infrastructure facilities:-}

Adequate and modern infrastructure powers is the emerging growth of a nation's economy. The absence of proper infrastructure can cause serious problems to an enterprise's daily business operations of manufacturing, consumption, and distribution of goods and services. It affects businesses at every level and ends up being a warning to healthy growth. The following reasons are the major consequences of the infrastructure facilities.

1. Lack of electricity resources

2. Inadequate supply of water

3. Lack of facilities like customized warehouse

4. Insufficient methods of industrial waste management

5. Inadequate cluster infra reducing competitiveness

6. Lack of reliable electricity resources

7. No minimum price for power fixed for MSME

8. Volatility in prices of basic fuels

\section{Absence of exclusive marketing platforms and distribution networks:-}

The nature of marketing changes the habits of customer.With consumer, habits changing rapidly it leads to competition from both local and global brands, market dynamics and customer loyalties are in a state of flux. While offering best-in-class products and services, enterprises also need to enhance the quality of customer interaction at each opportunity. Enhancing customer engagement is not a matter of choice anymore and to succeed, Market intelligence, tools and well-trained workforces are required to respond these external pressures. The below mentioned are the key reasons why domestic MSMEs in India are unable to approach marketing and distribution effectively.

1. Lack of monetary support/schemes

2. Knowledge about digital marketing is less

3. Limited expertise in new-age marketing

4. Lessaware of technology for marketing

5. Not enough trade fairs and buyer-seller meets

6. Due to lack of networks losing to large competitors

Inflexible labour laws and availability of affordable skilled labour:-

Indian MSMEs employ 40\% of the country's workforce, making them the employment powerhouse of the country. However, India today faces the big challenge of outdated labour laws that are still in use. Bigger organizations like Maruti too have faced labour problems in the recent past. This leaves many MSMEs struggling with problems of culture and scale and not being able to meet their workforce demands. A labour law reform overhaul is required to regulate large influx of workforce, which will enter the working landscape. The following points highlight some of the key issues that enterprises face related to workforce:

1. Retaining talent due lack of ability to pay

2. Low productivity of labours

3. Common minimum wage policies

4. Lack of skilled workers

Nonetheless, the sentiments towards Micro, Small \& Medium Enterprises is growing positive, putting them back in the spotlight. There is an expectation that their growth would be much faster over the next few years. However, the companies, which would emerge winners, would need to find a way around to leverage their strengths and remain ahead of intense competition. The use of technology to progress a competitive advantage would be key defining point to look out for having access to the right talent, adequate sources of funding will develop a 'value proposition', which embeds itself into the journeys of improving customers experience and benefit for the country as a whole. This has to be supported by a defined framework and deft handling of the challenges of MSMEs in India. 
Different types of ownership and Growth impacted by multiple constraints:-

There are more than five types of ownerships in MSMEs in India. Among them proprietorship of business is common $(94.5 \%)$ whereas the rest all-together only $5.5 \%$.

Ownership Structure of Enterprises in the MSME Sector:-

\begin{tabular}{|cc|}
\hline \multicolumn{2}{|c|}{ Ownership Structure in the Sector } \\
\hline Type of Structure & Share of MSME Enterprises \\
\hline Proprietorship & $94.5 \%$ \\
\hline Partnership, Cooperatives & $1.2 \%$ \\
\hline $\begin{array}{c}\text { Private Limited, Public } \\
\text { Limited }\end{array}$ & $0.8 \%$ \\
\hline Others & $3.5 \%$ \\
\hline
\end{tabular}

Source: MSME Census

Although the MSME sector has been growing at a faster rate than the overall industrial sector, MSMEs experience multiple constraints that threaten to further development of MSME. Some of key hindrances that MSMEs face

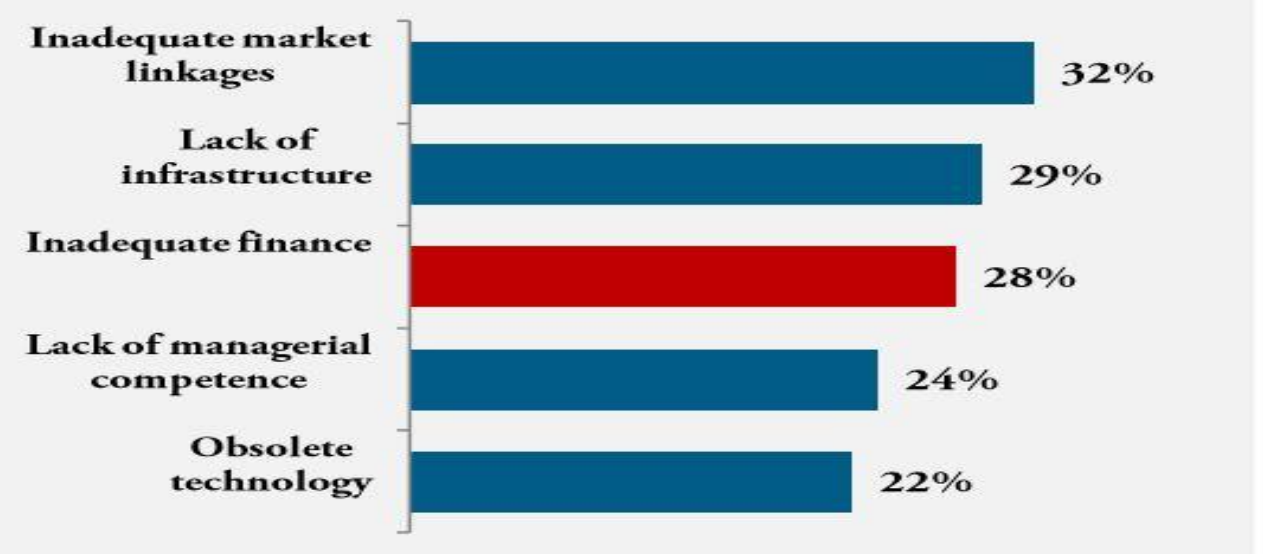

Source: Report of working group on rehabilitation of MSMEs RBI

\section{Lack of infrastructure:-}

Inadequacy of infrastructure such as power, water and roads upsurges operating costs for MSMEs and marks their businesses uncompetitive. Insufficient access to backing of infrastructure dejects these units from implementing newer technologies, where available.

\section{Inadequate finance:-}

MSMEs ponder encounters in accessing finance as one of the biggest constrictions in growth. Various researches on the MSME sector also proposes that the multiple growth constraints can be mostly related to insufficient access to finance.

\section{Lack of managerial competence:-}

Micro and small enterprises in particular largely comprise first-generation entrepreneurs, who have had a limited structured training on resource planning, capital management and labour management. 


\section{Outdated technology:-}

While large industries like automotive, forging, software development sector want cutting-edge expertise in operations, the majority of the small and medium enterprises are lacking the same. A low technology base outcome in low productivity, which makes these initiatives not reasonable in nature.

\section{Inadequate market linkages:-}

Other than cluster-linked and ancillary MSMEs that have natural linkages with large enterprises, MSMEs are having poor market access. The poor market linkage leads to poor profitability of MSME and hence, are unable to shape themselves to compete with the market in order to reduce purchase cost from large enterprises or reorganize the retail chain.

\section{Msme profitability:-}

Performance of MSME, Employment and Investments:-

As per the results of Fourth All India Census of MSME, the sector contributes significantly to the number of enterprises, employment and output of the country. Based on the data sets of Fourth All India Census of MSME, augmented with data sets of EC, 2005 and growth rate observed during Fourth (1998) and Fifth (2005) Economic Census, the performance of MSME.

\begin{tabular}{|l|l|l|l|l|}
\hline S.No & Year & $\begin{array}{l}\text { Total } \\
\text { Enterprises(in lakh) }\end{array}$ & $\begin{array}{l}\text { Employment } \\
\text { (in Lakh) }\end{array}$ & $\begin{array}{l}\text { Market Value of Fixed } \\
\text { Assets(Rs.in Crore) }\end{array}$ \\
\hline I & II & II & III & IV \\
\hline $\mathbf{1}$ & $2006-07$ & 361.76 & 805.23 & $868,543.79$ \\
\hline $\mathbf{2}$ & $2007-08$ & 377.36 & 842.00 & $920,459.84$ \\
\hline $\mathbf{3}$ & $2008-09$ & 393.70 & 880.84 & $977,114.72$ \\
\hline $\mathbf{4}$ & $2009-10$ & 410.80 & 921.79 & $1,038,546.08$ \\
\hline $\mathbf{5}$ & $2010-11$ & 428.73 & 965.15 & $1,105,934.09$ \\
\hline $\mathbf{6}$ & $2011-12$ & 447.64 & $1,011.69$ & $1,182,757.64$ \\
\hline $\mathbf{7}$ & $2012-13$ & 447.54 & $1,061.40$ & $1.268,763.67$ \\
\hline $\mathbf{8}$ & $2013-14$ & 488.46 & $1,114.29$ & $1,363,700.54$ \\
\hline
\end{tabular}

Number of enterprise in msme Sector:-

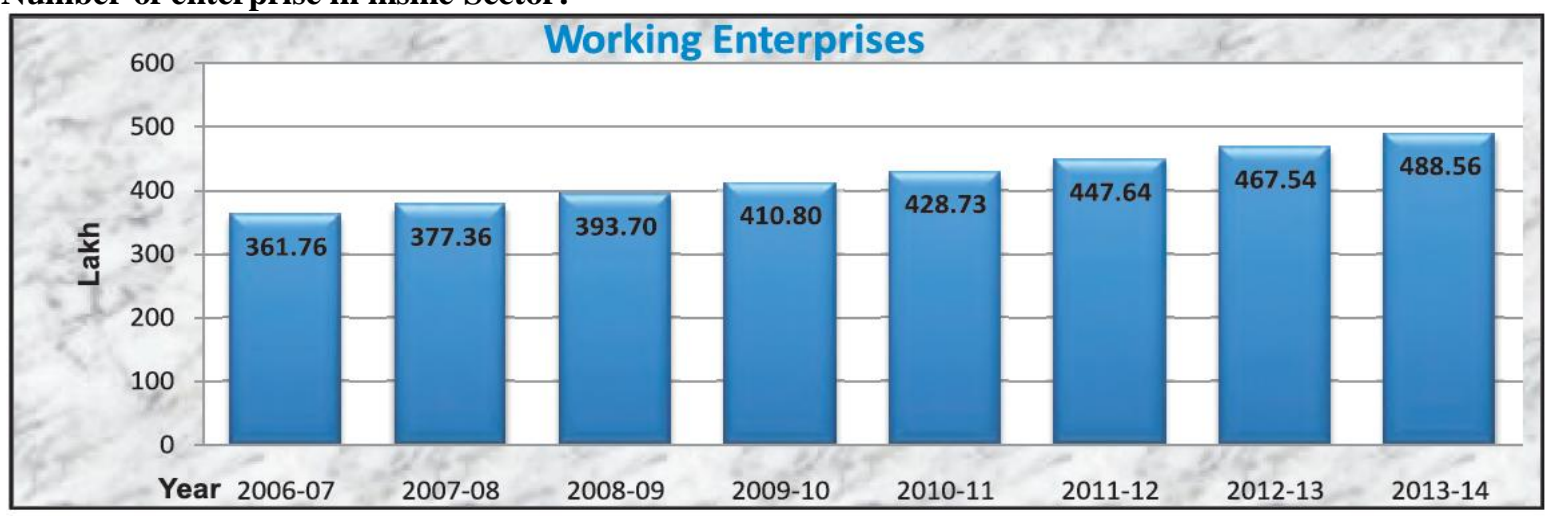

Projected data for the years 2007-08 to 2013-14 
Employment in MSMESector:-

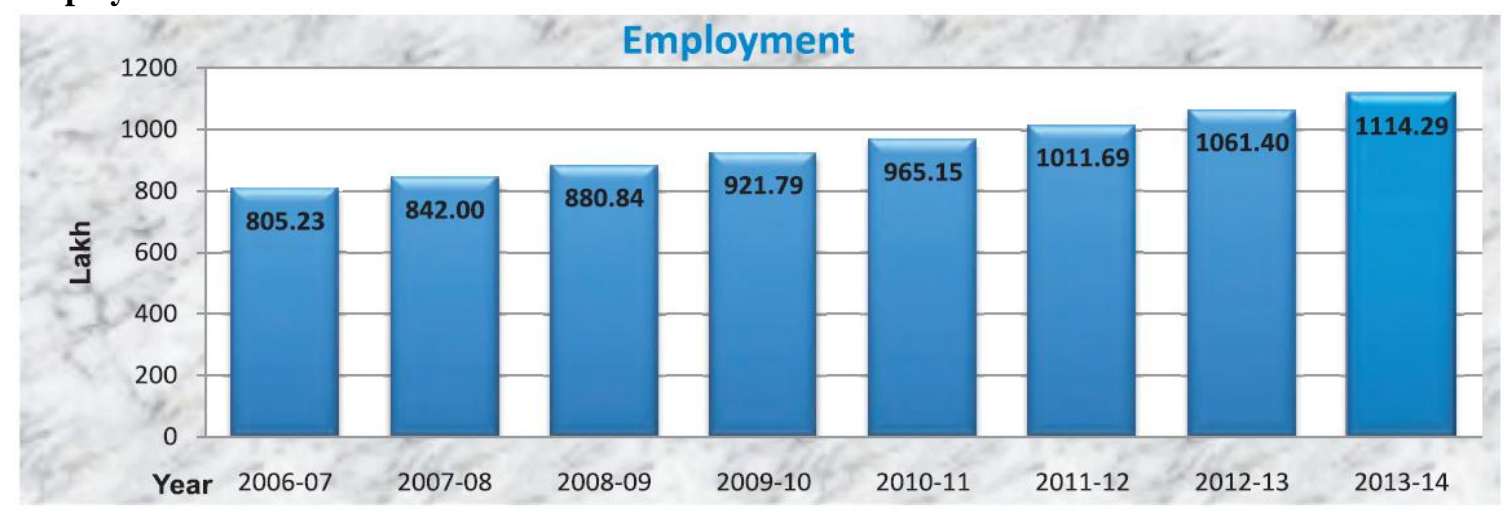

Projected data for the years 2007-08 to 2013-14.

Fixed investment in MSMESector:-

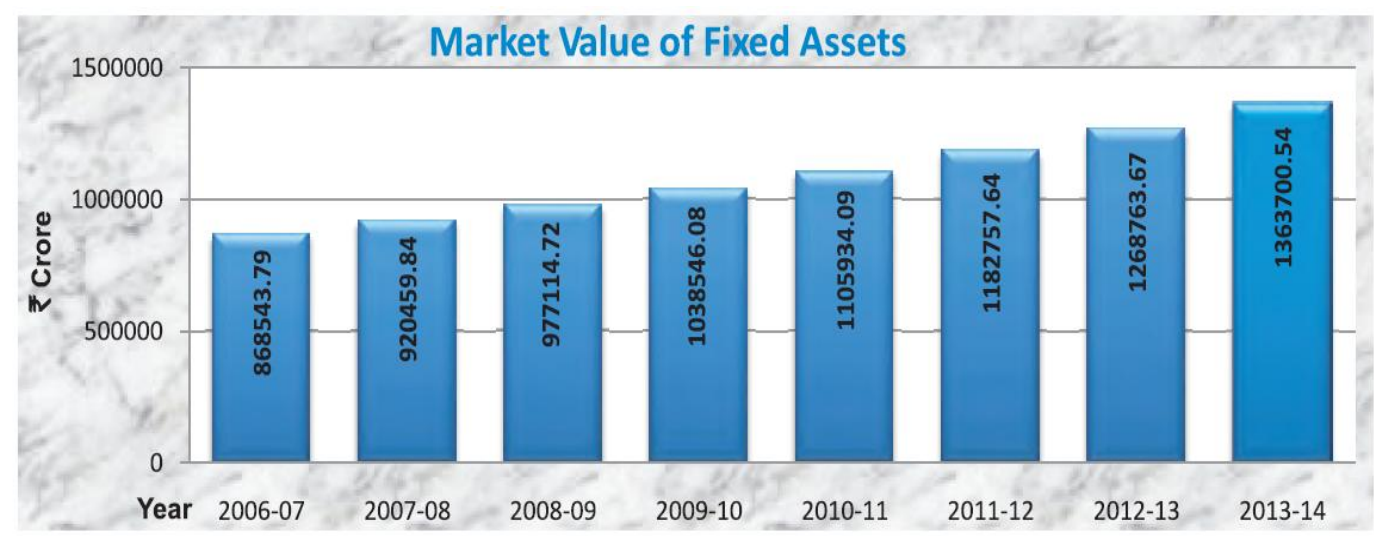

Projected data for the years 2007-08 to 2013-14.

\section{Interpretation:-}

As per the above given data it has been shown a gradual increase in context of performance of MSME, employment and investments from the dated year 2006-2014. In the year, 2006 the total working enterprises was Rs.361.76 in 2014 was Rs. 488.46 so the difference seen was Rs.126.7. In Employment in the year 2006, it was Rs.805.23 and in 2014, it was Rs. 1,114.29so the difference seen was Rs. 309.06. In Market Value of Fixed Assets in the year 2006, it was Rs. 868,543.79 and in 2014, it was Rs. 1,363,700.54so the difference seen was Rs. 4, 95, 156.75.

Contribution of manufacturing output of msme in GDP:-

\begin{tabular}{|l|l|l|l|l|l|}
\hline Year & $\begin{array}{l}\text { Gross Value of Output } \\
\text { of } \\
\text { Manufacturing } \\
\text { Sector('in crore) }\end{array}$ & $\begin{array}{l}\text { Share of MSME sector in total GDP } \\
(\%)\end{array}$ & $\begin{array}{l}\text { Share of } \\
\text { Manufacturing output in } \\
\text { Manufacturing } \\
\text { Otal } \\
\text { Output (\%) }\end{array}$ \\
\hline & & $\begin{array}{l}\text { Manufacturing } \\
\text { Sector MSME }\end{array}$ & $\begin{array}{l}\text { Services Sector } \\
\text { MSME }\end{array}$ & Total & \\
\hline $2006-07$ & 1198818 & 7.73 & 27.40 & 35.13 & 42.02 \\
\hline $2007-08$ & 1322777 & 7.81 & 27.60 & 35.41 & 41.98 \\
\hline $2008-09$ & 1375589 & 7.52 & 28.60 & 36.12 & 40.79 \\
\hline $2009-10$ & 1488352 & 7.45 & 28.60 & 36.05 & 39.63 \\
\hline $2010-11$ & 1653622 & 7.39 & 29.30 & 36.69 & 38.50 \\
\hline $2011-12$ & 1788584 & 7.27 & 30.70 & 37.97 & 37.47 \\
\hline $2012-13$ & 1809976 & 7.04 & 30.50 & 37.54 & 37.33 \\
\hline
\end{tabular}




\section{Interpretation:-}

The above given data shows the Contribution of Manufacturing output of msme in GDP from the dated year 20062013. In the year 2006 Gross value of output of msme manufacturing sectorwas Rs. 1198818 in 2013 Rs. 1809976 so the difference seen as Rs. 6,11,158. In Share of MSME sector in total GDP (\%) in the year 2006 Manufacturing Sector MSME shows $7.73 \%$ but in the year 2013 it has reduced to 7.04\% and Services Sector MSME in the year 2006, 27.40\% and in the year 2013 30.50\%. It shows a gradual increase in every year. So comparing both Manufacturing and Service Sector it was 35.13\% in 2006 an in 2013 37.54\% has been increased. Share of MSME Manufacturing output in total Manufacturing Output (percentage) was noticeable declining in the year 2013 compared to the year 2006

\section{Market linkage:-}

Market Linkage is a word give the real success essence to the MSME.It helps to connect the medium level business to top level where the medium enterprise can get various linkage. The objective of the market linkage is an attempt to combine the strengths of value chain analysis with the promotion of sustainable, market-based solutions that respond to the recurrent needs of micro, small, and medium scale enterprise (MSME). Market linkage is essential in understanding market potential, inter-firm relationships, and critical constraints that limit MSME growth and industry competitiveness, while market based, commercially viable solutions can result in solutions that are sustainable in the end and that do not distort local markets.

\section{Market linkage requires effective value chain to sustain:-}

Step 1: Value Chain Selection-Choose a value chain with the greatest potential for growth in MSME income and employment.

Step 2: Value chain Analysis - Gain a greater understanding of the operating context for MSMEs and intelligence on the market players, their roles, and interrelationships.

Step 3: Identification of obstacles and opportunities - Appropriately identify key issues hindering growth and competitiveness in the value chain.

Step 4: Identification of (Potential) Market linkage - Determine which sources can best address the obstacles identified in Step 3.

Step 5: Selection of suitable Market linkage Solutions - Target specific market-based solution(s) for more in-depth analysis.

Step 6: Assessment of Targeted Market-Based Solutions - Recogniselimitations to the viable supply/demand ofthe battered solution.

Step 7: Identification of Enabling Activities -Appropriately identify various activities helps to address the constraints of the target market based solution.

Step 8: Selection of Easing Activities - Choose the most suitable facilitation activities to implement.

\section{Msme Financing \&Strengthening Msme linkages:-}

1. India MSME units is $25 \%$ are presented in East and North - Easternregion. It was contributing GDP of $13 \%$ for our country. All are micro enterprises. The recent statistics say 4259 MSME clusters, 1086 industrial cluster and 2682 handicraft clusters in the Eastern and North Eastern region of India.

2. To develop MSME, theIndian government to conduct various programs like, Credit Guarantee Scheme, yet new MSME application registration has remained very low in the Eastern and North Eastern region compared to the Southern and Western side of the country. The rating coverage has not spread across this region properly.

3. Except west Bengal the regional imbalance, inadequate infrastrue, low income statistics dependence on agriculture are counted to be the major hindrance for the growth of MSME units in the region

4. The MSMEs faced problems like, non-availability of timely and adequate credit at reasonable interest rate is one of the barriers for growth of MSMEs, so the first generation entrepreneurs are not access to credit at reasonable interest rate. The high risk perception of the banks in lending to MSMEs and it is difficult for the micro and small entrepreneurs to set up new business or expand the existing one.

5. Tax submission of Micro and small enterprises has been very poor in India. Because of the high tax rates and complex filing procedures to lead crucial factor to MSME.

6. The Reduction of tax rate on the MSMEs to provide enough fund for expansion and better survival of MSMEs in viable market. The entrepreneurs need to engage to increase in tax exemptions and tax holidays. Therefore, those initiatives will also eventually attract investors who are potential taxpayers in future. 
7. The upcoming entrepreneurs need more update in the modern technology in packaging to increase the product competiveness not only in domestic market, but also in international market. The technology up gradation leads to good linkage in domestic as well as international market.

8. The MSME earning level is very low so theydo not reveal their financial pattern. Therefore, it leads to limited transparency between bank and the entrepreneurs to establish direct linkage between banks the MSME entrepreneurs.

9. Technology and IT services play a vibrant role for the growth of MSMEs. Most of the investments are currently done in traditional technology, but they should follow the new trends to expand the technology. Investment should rise in R\&D, particularly in areas of emerging technologies including mobility, data analytics and cloud computing to improve the core business.

10. Creation of social entrepreneurs is preferred to encourage e-commerce among rural consumers. There lies a possible market for e-commerce in rural areas, which can be explored by undertaking certain policy initiatives and using modern technological tools.

11. The high constraints of MSME units in the form of land acquisition, availability of power, transport, logistics, credit disbursal, skilled labor, adequate marketing initiatives and issues in taxation. The essential issues should be addressed by the government for the growth of MSMEs

12. Absence of innovative initiatives and interest among people are counted as the major reasons for this region to lag behind. They have to supper awareness among youth about entrepreneurship and they need to be encouraged.

\section{Conclusion:-}

Micro, Small and Medium Enterprises (MSMEs) contribute to economic development in various ways such as creating employment opportunities for rural and urban population, providing goods \& services at affordable costs by offering innovative solutions and sustainable development to the economy as a whole. The MSMEs continues to struggle on proper market linkage. In present scenario government frame many policies that will give benefit to the MSME to earn minimum profit and the policies. However, it is not enough to getting linkage with blue chip companies. The companies initiate to give some orientation to MSME's and lead to successful linkage. While credit and finance issues challenge some, others are struggling to cope with stringent regulatory environments. The role and importance of MSME sectorin the vital growth. The problems MSMEs face which also become the reason for slow-paced growth of this sector and these have been detailed in the paper. In a close, this paper has tried to offer some suggestions to overcome those challenges and offer a ray of hope for the MSME sector in India.

The need for enterprise to increase market coverage, improve operational efficiencies and enhance customer engagement is imperative. However, this requires readiness on two accounts-the company and government regulation and policies, including MSME special programs, initiatives and funds.

\section{Reference:-}

1. Aliyu mukhtar shehu and Rosli mahmood, August (2014) The Relationship between Market Orientation and Business Performance of Nigerian SMEs: The Role of Organizational Culture, International journal of business and social science, School of business management, Malaysia.

2. World Bank (1994) Industrial Structures and the Development of Small and Medium Enterprise Linkages: Examples from East Asia, Meyanathan, EDI Series, World Bank

3. FICCI-CMSME(Aug 19,2014)MSME Definition in India: The Present State and the imperatives

4. Government of India MSME:MSME at a Glance 2016

5. Dr.Mukund Chandra Mehta, $2^{\text {nd }}$ International Conference on Management, Humanity and Economics(2013) kuala Lampur (Malaysia), Challenges and Opportunities in Micro, Small and Medium Enterprises in India

6. IFC(International Finance Corporation) World Bank Group (Nov 2012) MSME A Research Study On Need, Gaps and Way Forward.

7. Prof. Mishu Tripathi.Mr.Saurabh Tripathi,Mr.RikinDedhia,International Journal Of Science Technology and Management (march 2016), Challenges Faced by Micro,Small and Medium Enterprises Sector in India.

8. Government of India, Ministry of MSME, Annual Report(2014-15)

9. Brij Raj. Challenges in SME financing. Developing alternative financing source. Skoch Development Foundation

10. Pankaj Trivedi, K.J.Somaiya Institute of Management Studies and Research, Mumbai, 12th AIMS International Conference on Management: Strategy for Profitable Growth through MSME Lending by Indian Banks. 
11. Development Commissioner MSME,Ministryof Micro, Small\& Medium Enterprises(2014-15)Entrepreneurs Memorandum (Part II)Data On MME Sector

12. Department of Agriculture, Forestry \& Fisheries,(oct 2012):Linking Procedures to market programme

13. Sylvia S. Temu \& Esther K. Ishengoma,Indian Journal Of Economics \& Business(June 2010):Financial Linkages and Performance of Rural Microfinance Cooperatives: Tanzanian case

14. Jayne Bisman \& Neelam Goela, Indian Journal Of Economics \& Business (December 2010):The Small Industries Development Bank of India: A Retrospective on SME Financing

15. Dossani,\& Kenney.M(2002), creating and Environment for Venture Capital in India. World Development,30(2),pp.227-253 